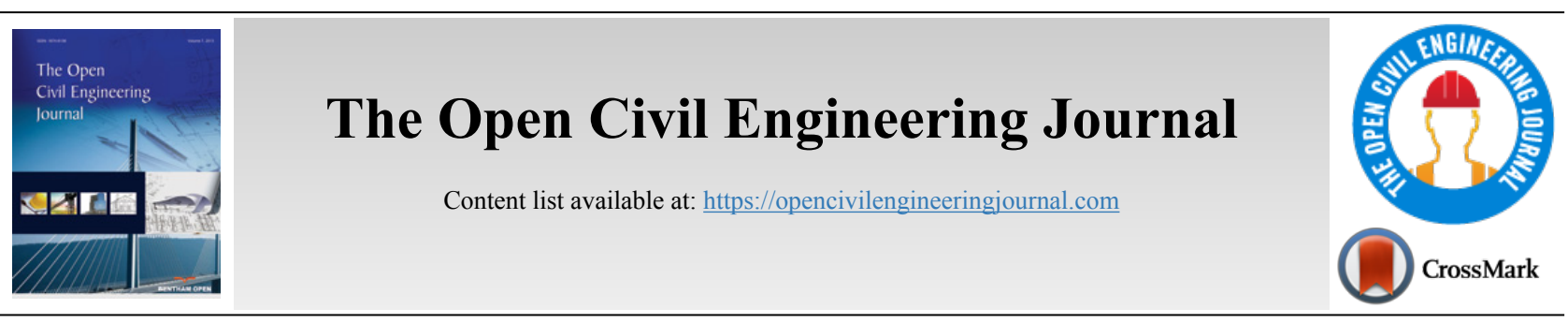

RESEARCH ARTICLE

\title{
Project Manager Interventions in Occupational Health and Safety During the Pre-construction Phase in the Gaza Strip
}

\author{
Bassam A. Tayeh ${ }^{1, *(D)}$, Rola O. Yaghi ${ }^{1(D)}$ and Yazan I. Abu Aisheh ${ }^{2}$ \\ ${ }^{l}$ Civil Engineering Department, Faculty of Engineering, Islamic University of Gaza, Gaza, Palestine \\ ${ }^{2}$ Department of Civil Engineering, Middle East University, Amman, Jordan
}

\begin{abstract}
:
Background:

Construction industry is classified as one of the most dangerous industries, where workers are exposed to accidents and risks.

Objective:

This study inspected the role of project manager in promoting Occupational Health and Safety (OHS) during the pre-construction phase in the construction projects in the Gaza Strip. Previous studies were reviewed in order to extract the impact of inadequate health and safety interventions in the construction projects throughout the world, and their applicability in the Gaza Strip was determined.

Methods:

This was achieved through a pilot study and a draft questionnaire. The questionnaire was developed in order to assess and evaluate the perception of project managers on the extent of their roles in promoting health and safety in the pre-construction phase. The sample size was 101 , out of which, 77 completed questionnaires were returned by the respondents.

Results:

The study revealed that two project parameters, mainly affected by inadequate health and safety interventions, were quality and labour productivity. The main stage during which a project manager played a significant role in promoting health and safety was the planning stage, with "identifying specific safety issues from prior experience" being the highest sub-factor, which was followed by the designing stage, with "plan works at the design phase through a time schedule, citing the duration of processes, divided into steps and any process priority" being the highest sub-factor.

\section{Conclusion:}

Finally, there was the tendering stage, with "make ensure that facilities are provided on site for first aid and emergency medical treatment in the event of an accident" being the highest sub-factor. The results of this study show great awareness of a project manager in promoting health and safety in the pre-construction phase.
\end{abstract}

Keywords: Occupational health and safety, Project manager, Pre-construction phase Gaza strip, Health and Safety (H\&S) risks, Construction Industry (CI), Gross Domestic Product (GDP).

\section{INTRODUCTION}

The construction sector is one of the most important sources of economic growth not only in the developed countries but also in the developing countries, where it is one

" Address correspondence to this author at the Department of Civil Engineering, Faculty of Engineering, Islamic University of Gaza, Gaza, Palestine; Tel: 00972595174717; E-mail: btayeh@iugaza.edu.ps of the leading sectors as well as the main contributor to their Gross Domestic Product (GDP) [1].

Previous research indicates that construction projects in Palestine account for $15.4 \%$ of its GDP [2]. The Construction Industry (CI) employs the largest labour force in the world [3]. According to the Palestinian Central Bureau of Statistics (PCBs), the Palestinian CI employs $15.7 \%$ of the total labour force [4]. 
$\mathrm{CI}$ is considered one of the most dangerous industries, where the workers are vulnerable to accidents and hazards. The construction industry is more dangerous and susceptible to Health and Safety (H\&S) risks than other industries due to the methods of construction, construction materials, use of heavy equiproject managerent, workers' careless attitudes towards $\mathrm{H} \& \mathrm{~S}$, poor leadership, and limited involvement of the clients as well as the project manager in H\&S [5]. In addition, with CI comprising temporality, movement, high turn-over rate, complexity of the environment, and the fragmented structure of the construction sector [6,7], this type of organisation makes management tasks difficult and complex. Another reason that makes the management of this sector more disturbing is a large number of workers [8]. As mentioned above, $\mathrm{CI}$ is considered one of the most employment-generating industries; consequently, paying attention to workers' H\&S-related matters becomes an essential issue [9].

In the past, $\mathrm{H} \& \mathrm{~S}$ was seen as an activity that only focused on the production site. However, now it has become holistic by integrating the responsibilities of all the stakeholders throughout the whole construction processes. Construction accidents not only impact the workers involved in the construction but also on the project parameters, meaning that the work itself suffers through construction delays and productivity losses [10]. Productivity is considered one of the most important factors affecting the entire performance of any organisation. Therefore, improving labour productivity is an effective tactic to increase the total productivity of the industry [11].

In the developing countries, the construction workforce is not considered an important resource input. Although workers in projects constitute the largest portion of the total projects costs, they account for up to $40 \%$ of the direct costs of huge projects. Since workers make up the largest proportion of the cost of construction, improvement of performance should be a major concern for achieving a project's objectives [12]. However, even though studies have been conducted with various parties in the construction process, few have inspected the role of the project manager (owner's representative) in promoting $\mathrm{H} \& \mathrm{~S}$ in the pre-construction phase. Many researchers consider that project managers play a dynamic role in the success or failure of the projects [4] due to their position as project leaders and coordinators. Therefore, project managers are appointed to incorporate $\mathrm{H} \& \mathrm{~S}$ in the overall phases of the construction procedures [13]. Integration of H\&S-related issues in all the aspects of the construction projects was considered a success factor [14].

The aim of this study was to promote Occupational Health and Safety (OHS) in the construction projects in the Gaza Strip throughout the pre-construction phase. This objective was achieved by identifying the impact of inadequate $\mathrm{H} \& \mathrm{~S}$ on project parameters and demonstrating the roles of project managers on H\&S in the CI in the Gaza Strip during the preconstruction phase (i.e., planning, designing, and tendering).

\section{LITERATURE REVIEW}

\subsection{OHS in the Gaza Strip}

In most of the developing countries, it is challenging to obtain an accurate number of injuries and victims in the CI because many of these accidents are not reported [15]. In the Gaza Strip, there is a lack of safety applications within the CI.
Consequently, the construction accident rate is nearly $20 \%$ of all the industrial injuries and is higher than the other industry accident rates. Contractors consider H\&S as not an investment but a cost, although legally they are responsible for it [16].

The latest unpublished statistics obtained from the Ministry of Labour in the Gaza Strip, pertaining to the year 2017, indicates that the number of officially registered injuries in occupational accidents is 192, out of which 93 injuries are in the CI. Moreover, the construction accident rate is $57.92 \%$ of all the industrial injuries, which is considered a dangerous rate. According to the same statistics, the total registered fatalities in the same year (2017) were 4 from a total of 192 injuries. With the total financial compensation for registered injuries estimated at about $\$ 1,418,906.91$, the average rate for each case of injury is $\$ 7024.29$, with 8640 days as sick leaves, which, economically, is considered a high cost that has negative effects on the GDP. As the safety record in the Gaza Strip is very weak, there is a need to improve safety in the CI through increasing the project managers' awareness of issues related to $\mathrm{H} \& \mathrm{~S}$.

To this day, many workers face accidents and health problems and suffer from ill health, which negatively affects their productivity. A study conducted by Enshassi et al. (and cited by $[17,18]$ ) revealed that out of the 45 factors that affect labour productivity in the Gaza Strip, 7 important factors were under the H\&S group. Moreover, according to a study [17], there were 4 important factors under the H\&S group, which are as follows: implementation of H\&S factors in the organisation, proportion of reportable accidents in the projects, the rate of assurance of the project, and safety to reach the location of the project.

\subsection{The Role of Project Manager in Construction Health and Safety}

Traditionally, a project manager concentrates on three parameters, cost, time, and quality. However, this old style has not been successful, because a great number of projects have gone over budget, with poor quality and delays. Therefore, project managers need to focus on H\&S-related issues by integrating their roles in $H \& S$ throughout the project [12]. In addition, [19] a study identified that a project manager contributes to H\&S-related issues and ranks second inauthority when compared to other stakeholders.

An appointed project manager has the responsibility to coordinate and integrate $\mathrm{H} \& \mathrm{~S}$ plans into the project during the preconstruction phase and monitor its full implementation on site [12].

A project manager has a pivotal role in ensuring coordination, integration, and implementation of the project's H\&S plans on site [20]. Moreover, according to a study [21], a project manager also has an important role in setting and achieving high standards. Additionally, he also controls contracts related to how the project is undertaken and how the designers and contractors are selected.

OHS is not only important in the construction stage of a construction project management but also throughout all of the project's lifecycle. This study focused on promoting H\&S in 
construction projects during the pre-construction phase, which is considered a proactive measure of mitigating and prevents accidents in the implementation phase [12]. Furthermore, the ability to impact the characteristics of the final project is higher at the beginning of the project, but reduces during the progress of the project [22].

\subsection{Construction Project Lifecycle}

Construction project management is divided into 3 phases, pre-construction, construction, and post-construction [23]. Fig. (1) shows the project lifecycle and its stages in each phase [24].
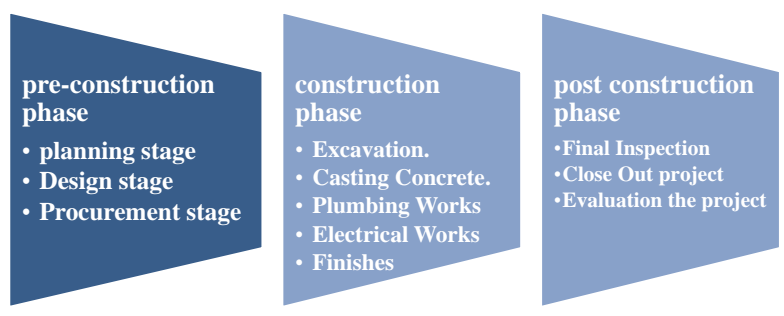

Fig. (1). Construction project lifecycle [24].

\subsection{OHS During the Pre-construction Phase}

As mentioned above, pre-construction stage is the first stage of any construction project management. Therefore, a previous study explains that planning, designing, and tendering are the "upstream" tasks, while construction is the "downstream" task. Moreover, it suggests that OHS should be emphasized more in the "upstream" tasks and not only the "downstream" tasks [23].

In the construction projects, OHS-related issues are not restricted to the construction stage but also appear during the whole of the project's lifecycle. Most of the H\&S-related problems that occurred during the construction phase can be eliminated if given more effort during the pre-construction phase of the project [23]. This is in consideration of the fact that the H\&S requirements in the pre-construction phase have been identified as an effective and successful technique in managing OHS because it decreases risks from their source [23].This contention is supported by the findings of a study
$[20,25]$, which indicate that the essential causes of accidents can be mostly divided into three portions: as a result of a decision of design, poor planning, and construction procedures and methods.

Practically, mitigating the potential of the factors that were a source of damage means executing the procedures, which make the factors safer. Hence, OHS in the pre-construction phase has an important effect on the H\&S-related results of the projects [26]. Nowadays, the promotion of OHS in the preconstruction tasks such as planning, designing and tendering is becoming essential. Construction workers safety must be the main concern of the planners and designers, which should be followed up by the project manager (owner's representative) [25].

The planning and designing phases give an opportunity to mitigate harms and risks before they take place at the job site, and this ability to mitigate risks is reduced while the project is progressing [27].

Therefore, the project manager (owner's representative) should integrate OHS during the pre-construction phase in order to achieve success [23].

\section{RESEARCH METHODOLOGY}

A questionnaire survey was used in order to achieve the research objective. The main purpose of this study was to determine the extent to which a project manager plays a role in promoting OHS in the pre-construction phase in the Gaza Strip. The methodology included questionnaire design, a justification of the survey instruments, data collection, and confirmation of empirical findings, which were designed for the study.

About 5 factors were identified with respect to inadequate $\mathrm{H} \& \mathrm{~S}$ and their impact on project parameters. Moreover, about 43 factors were selected from the previous literature, with respect to the roles and responsibilities of the project manager in promoting OHS in the construction projects in all the stages in the pre-construction phase. All the factors are reviewed in Table 1. While some of these factors have been modified, others have been merged or added through the process of questionnaire evaluation. Additionally, some items have been deleted.

\section{Table 1. Summary of the literature review of project manager's role factors in the pre-construction phase.}

\begin{tabular}{|c|c|c|c|c|c|c|c|c|c|c|c|c|c|}
\hline \multirow{3}{*}{ S.No } & \multirow{3}{*}{$\begin{array}{l}\text { A Project Manager's Role and Responsibility Factors in the Pre-Construction } \\
\text { Phase }\end{array}$} & \multicolumn{12}{|c|}{ References } \\
\hline & & {$[28]$} & [29] & {$[30]$} & {$[31]$} & {$[32]$} & {$[33]$} & {$\left[\begin{array}{c}12 \\
1\end{array}\right.$} & {$[34]$} & {$[35]$} & {$[36]$} & {$[37]$} & {$[38]$} \\
\hline & & 1 & 2 & 3 & 4 & 5 & 6 & 7 & 8 & 9 & \begin{tabular}{|l|}
10 \\
\end{tabular} & 11 & 12 \\
\hline 1 & Setting H\&S objectives & - & - & - & - & - & - & - & - & $\sqrt{ }$ & - & - & - \\
\hline 2 & Categorising the tasks of the project within OHS implications & - & - & - & - & - & - & $\sqrt{ }$ & - & $\sqrt{ }$ & - & - & - \\
\hline 3 & $\begin{array}{l}\text { Making a worksheet for sorting risks associated to the construction activities } \\
\text { according to the hazard types of fall, slip, trip, struck by object or equi-project } \\
\text { management, etc }\end{array}$ & - & - & - & - & - & - & $\sqrt{ }$ & - & $\sqrt{ }$ & - & - & - \\
\hline 4 & Consulting workers on H\&S matters & $\sqrt{ }$ & - & - & - & - & - & - & $\sqrt{ }$ & - & - & - & - \\
\hline 5 & Picking a professional consultant who makes a safe design & $\sqrt{ }$ & - & - & - & - & - & - & - & - & - & - & - \\
\hline 6 & $\begin{array}{l}\text { Making sure that client allocates definite funds to promote health and safety in } \\
\text { project. }\end{array}$ & $\sqrt{ }$ & - & - & - & - & - & - & - & - & $\sqrt{ }$ & - & - \\
\hline 7 & Allowing adequate time and resources during all the stages of the project. & - & - & - & $\sqrt{ }$ & - & - & - & $\sqrt{ }$ & - & - & - & - \\
\hline
\end{tabular}


(Table 1) contd.....

\begin{tabular}{|c|c|c|c|c|c|c|c|c|c|c|c|c|c|}
\hline \multirow{3}{*}{ S.No } & \multirow{3}{*}{$\begin{array}{c}\text { A Project Manager's Role and Responsibility Factors in the Pre-Construction } \\
\text { Phase }\end{array}$} & \multicolumn{12}{|c|}{ References } \\
\hline & & {$[28]$} & [29] & {$[30]$} & {$[31]$} & {$[32]$} & {$[33]$} & {$\left[\begin{array}{c}{[12} \\
]\end{array}\right.$} & [34] & {$[35]$} & {$[36]$} & {$[37]$} & {$[38]$} \\
\hline & & 1 & 2 & 3 & 4 & 5 & 6 & 7 & 8 & 9 & 10 & 11 & 12 \\
\hline 8 & Providing free health and safety training for the client staff & - & - & - & - & - & - & $\sqrt{ }$ & $\sqrt{ }$ & - & - & - & - \\
\hline 9 & Defining ways to promote and consolidate OHS in the tender stage & $\sqrt{ }$ & - & - & - & - & - & $\sqrt{ }$ & - & - & - & - & - \\
\hline 10 & Changing the mind of the designers towards safety & - & - & - & - & - & - & - & - & - & $\sqrt{ }$ & - & $\sqrt{ }$ \\
\hline 11 & Integrating $\mathrm{H} \& \mathrm{~S}$ information into the drawings & - & - & - & - & - & - & $\sqrt{ }$ & - & - & - & $\sqrt{ }$ & - \\
\hline 12 & Providing a motivational energy to enhance the principle of safe design & $\sqrt{ }$ & - & - & - & - & - & - & - & - & - & - & $\sqrt{ }$ \\
\hline 13 & $\begin{array}{l}\text { Ensuring that risky material is taken into consideration when determining the } \\
\text { materials }\end{array}$ & - & $\sqrt{ }$ & - & - & - & - & $\sqrt{ }$ & - & - & - & - & - \\
\hline 14 & Integrating the principles of constructability into the design & $\sqrt{ }$ & - & $\sqrt{ }$ & - & - & - & - & - & - & - & - & - \\
\hline 15 & Controlling design change & - & - & - & - & - & - & - & - & - & - & $\sqrt{ }$ & $\sqrt{ }$ \\
\hline 16 & $\begin{array}{l}\text { Establishing reasonable regulation when new structures, materials, or techniques } \\
\text { are approved in the project }\end{array}$ & - & - & - & - & - & - & - & - & - & $\sqrt{ }$ & $\sqrt{ }$ & - \\
\hline 17 & $\begin{array}{l}\text { Planning tasks at the design phase through a time schedule, citing the duration of } \\
\text { processes and dividing it into steps and process priority }\end{array}$ & - & - & - & $\sqrt{ }$ & - & - & $\sqrt{ }$ & - & - & - & - & - \\
\hline 18 & $\begin{array}{l}\text { Ensuring that OHS is a portion of the main objectives of the project and it is } \\
\text { comprised at the subject of the tender }\end{array}$ & - & - & $\sqrt{ }$ & - & - & - & $\sqrt{ }$ & - & - & - & - & - \\
\hline 19 & $\begin{array}{l}\text { Understanding the market to evaluate the ability of the contractors in the local } \\
\text { market to achieve the required standards }\end{array}$ & $\sqrt{ }$ & - & - & - & - & - & $\sqrt{ }$ & - & - & - & - & - \\
\hline 20 & $\begin{array}{l}\text { Formulating an H\&S-documented specification, particularly for the construction } \\
\text { works }\end{array}$ & - & - & - & - & $\sqrt{ }$ & - & $\sqrt{ }$ & - & - & - & - & - \\
\hline 21 & Using pre-qualifications for the contractor and taking OHS into consideration & - & - & - & - & - & $\sqrt{ }$ & $\sqrt{ }$ & - & - & - & - & - \\
\hline 22 & $\begin{array}{c}\text { Selecting only those subcontractors who have a good record and provide on-the-job } \\
\text { training }\end{array}$ & $\sqrt{ }$ & - & - & - & - & - & - & - & $\sqrt{ }$ & - & - & - \\
\hline 23 & $\begin{array}{l}\text { Ensuring that principal contractors have made provision for the H\&S-related costs } \\
\text { in their tenders." }\end{array}$ & - & - & - & - & $\sqrt{ }$ & - & - & - & - & - & - & $\sqrt{ }$ \\
\hline 24 & $\begin{array}{l}\text { Requiring the contractor to include the programme to combat drug abuse, } \\
\text { stimulants, child labour, etc. in the contractor's OHS programme. }\end{array}$ & - & $\sqrt{ }$ & - & - & - & - & - & - & $\sqrt{ }$ & - & - & - \\
\hline 25 & $\begin{array}{c}\begin{array}{c}\text { Ensuring that the contractor places at least one full-time H\&S representative on the } \\
\text { project }\end{array} \\
\end{array}$ & - & $\overline{\sqrt{ }}$ & - & - & - & - & $\sqrt{ }$ & - & - & - & $\sqrt{ }$ & - \\
\hline 26 & $\begin{array}{c}\text { Ensuring that appropriate Personal Protective Equiproject managerent (PPE) is } \\
\text { provided to all the workers free of charge }\end{array}$ & $\overline{\sqrt{ }}$ & - & $\sqrt{ }$ & - & - & $\sqrt{ }$ & $\sqrt{ }$ & - & - & - & - & - \\
\hline
\end{tabular}

\subsection{Research Population and Sample}

The research population was mainly limited to four categories: (1) governmental institutions, (2) international institutions, (3) non-governmental institutions (NGOs), and (4) the offices of engineering consultants, who play the role of the owner's representatives.

The research sample consisted of engineers who work as project managers, consultants who were employed in construction projects and had five or more years of experience in construction projects. The questionnaire was submitted only to the construction project owners or their representatives. The following formula determined the sample size of infinite population:

For infinity population,

$$
S S=\frac{\mathrm{z} 2 \times \mathrm{P} \times(1-\mathrm{P})}{C^{2}}=\frac{1.96^{2} \times 0.5 \times(1-0.5)}{0.05^{2}}=384
$$

Here,

\section{SS: Sample Size.}

$\mathrm{Z}$ : $\mathrm{Z}$ value (e.g., 1.96 for $95 \%$ confidence interval).

P: Percentage picking a choice, expressed as decimal ( 0.50 used for the sample size needed).
C: Confidence interval expressed as decimal (0.05).

The general rule relative to the acceptable margins of error (i.e., a precision) in categorical data research is $5 \%$. In this study, the population was 1924 , and the ratio between the obtained sample size and the population was 0.2 (384/136), which is larger than 0.05 . Therefore, the corrected sample size for finite population could be used, for which, the sample size was calculated as follows"

$$
S S_{\text {new }}=\frac{S S}{1+\frac{S S-1}{\text { Pop }}}=\frac{384}{1+\frac{384-1}{136}}=101
$$

Here, "pop" refers to the total population

The method of sampling that was followed in this study was stratified random sampling. The population was divided into different categories in order to get a sample that represented the population. The stratified sample was found by taking samples from each category, which was calculated by the following equation:

$$
(S S)_{i}=\frac{(\text { pop })_{i}}{\text { research population }} \times \text { research sample size }
$$

Here, 
(SS)i: The sample size of the category $\mathrm{i}$

(pop)i: Population of the category $i$

It was clarified that only 77 questionnaires were collected, which were less than the sample size of 101 because many of the targeted elements did not have enough time to respond. However, the total returned percentage was considered to be acceptable as it was nearly $76.24 \%$.

\subsection{Pilot Study}

The pilot study for the questionnaire was carried out in order to test the appropriateness, validity, and reliability of the questionnaire. It provided a trial run of the questionnaire, which involved testing the wordings of the questions, identifying ambiguous questions, testing the techniques that were used to collect the data, and measuring the effectiveness of the standard invitation to the respondents. This pilot study was divided mainly into two stages, which are as follows: in the first stage, the questionnaire was consulted by (5) Palestinian experts who had more than ten years of experience in construction projects and an academic background in questionnaire assessment and making adjustments that best fit the Palestinian conditions. In the second stage, the ques-tionnaire was validated by the criterion-related reliability test, which measures correlation coefficients between the factors selected for one group and the whole group, and the structure validity test.

\subsection{Questionnaire Design}

The questionnaire included multiple-choice questions. The variety in these questions aimed at meeting the research objectives related to the role of a project manager in promoting construction H\&S during the pre-construction phase in the Gaza Strip and collecting all the necessary data that can support the discussion, results, and recommendations in the study. The structure of the questionnaire was divided into three parts: (i) general information related to the institution and respondents, (ii) the impact of inadequate H\&S interventions on project parameters, and (iii) the extent of implementation of the roles and responsibilities of the project manager in promoting OHS in construction projects in the Gaza Strip during the pre-construction phase.

The numerical rating scale (5-point Likert scale) was chosen in order to format the questions of the questionnaire, as shown in Table 2.

Table 2. : The numerical rating scale (the five-point Likert scale) in each field of the questionnaire.

\begin{tabular}{|l|c|c|c|c|c|}
\hline Scale & $\begin{array}{c}\text { Very Low } \\
\text { Degree }\end{array}$ & $\begin{array}{c}\text { Low } \\
\text { Degree }\end{array}$ & $\begin{array}{c}\text { Average } \\
\text { Degree }\end{array}$ & $\begin{array}{c}\text { High } \\
\text { Degree }\end{array}$ & $\begin{array}{c}\text { Very High } \\
\text { Degree }\end{array}$ \\
\hline Degree & $(1)$ & $(2)$ & $(3)$ & $(4)$ & $(5)$ \\
\hline
\end{tabular}

\subsection{Proportional Weight}

Descriptive statistics through proportional weight method were used in order to decide the ranks of the performance factors and highlight the proportional weight of the attributes as supposed by the respondents. In previous studies, several researches $[39-48,51]$ used the proportional weight in their analysis. It is expressed in the following manner:

$$
\bar{X}_{W}=\frac{\sum W}{A N}=\frac{5 n_{5}+4 n_{4}+3 n_{3}+2 n_{2}+1 n_{1}}{5 N}
$$

Here,

$\mathrm{W}=$ the weighing of each factor (ranging from 1 to 5 )

$$
\begin{aligned}
& \mathrm{A}=\text { the top weight } \\
& \mathrm{N}=\text { the entire number }
\end{aligned}
$$

The range of proportional weight is between 0 and 1 , where the higher the proportional weight, the more the impact. However, in the study, the proportional weight did not illustrate the relationship between the attributes.

\section{FINDINGS AND DISCUSSION}

4.1. General Information Related to the Institution and Respondent (Table 3)

Table 3. Background information of the respondents.

\begin{tabular}{|c|c|}
\hline Background information & Percent (\%) \\
\hline Type of institution & - \\
\hline Governmental & 20.8 \\
\hline International & 41.6 \\
\hline Non-Governmental & 5.2 \\
\hline Consultant & 32.5 \\
\hline Job title of the respondent & - \\
\hline Consultant Engineer & 11.7 \\
\hline Office Engineer & 28.6 \\
\hline Project Manager & 32.5 \\
\hline Tender Directorate & 10.4 \\
\hline Site Engineer & 16.9 \\
\hline The respondent's years of experience & - \\
\hline Less than 5 years & 6.5 \\
\hline 5-less than 10 years & 24.7 \\
\hline
\end{tabular}


(Table 3) contd.....

\begin{tabular}{|c|c|}
\hline 10-less than 15 years & 29.9 \\
\hline More than 15 years & 39.0 \\
\hline The experience for the institution in the construction projects & - \\
\hline Less than 10 years & 15.6 \\
\hline 10 -less than 15 years & 16.9 \\
\hline 15-less than 20 years & 14.3 \\
\hline More than 20 years & 53.2 \\
\hline The number of construction projects executed or supervised by the institution within the last 5 years & - \\
\hline Less than 10 years & 7.8 \\
\hline 10-less than 20 years & 18.2 \\
\hline 20-less than 30 years & 18.2 \\
\hline More than 30 years & 55.8 \\
\hline
\end{tabular}

\subsection{Analysis of the Fields}

For this section of the study, each field was analysed using the descriptive statistics (means, Standard Deviations [SD], tvalue [two tailed], probabilities [ $P$-value], and Relative Importance Indices [RII]). Finally, the ranks were established.

All this was done in order to determine the degree of the responses of the sample participants concerning the fields as well as the items within the fields. These works were ranked by the mean of the responses. Moreover, a 5-point Likert scale was used, in which "very high degree" $=5$, "high degree" $=4$, "average degree" $=3$, "low degree" $=2$, and "very low degree" $=1$.

\subsection{The Impact of Inadequate H\&S Interventions on Project Parameters}

The results illustrated that the total average of all the items in the first field (i.e., the impact of inadequate $\mathrm{H} \& \mathrm{~S}$ interventions on project parameters) was equal to 3.61 , with the T-test 8.64 and the $P$-value 0.000 , which is less than 0.05 . This indicates that inadequate $\mathrm{H} \& \mathrm{~S}$ interventions have a high impact on the project parameters mentioned in Table 4. Moreover, the SD was also used in order to quantify the amount of variation or dispersion of respondent opinions regarding the impact of inadequate $\mathrm{H} \& \mathrm{~S}$ interventions on project parameters. As shown in Table 4, the average SD was 0.62 , which indicates that the results pertaining to the respondents are consistent and not spread out over a wider range of values, suggesting that the results are confident.

Table 4. The impact of inadequate $\mathrm{H} \& \mathrm{~S}$ interventions on project parameters.

\begin{tabular}{|c|c|c|c|c|c|c|c|}
\hline No. & $\begin{array}{c}\text { Project } \\
\text { Parameter }\end{array}$ & Mean & $\begin{array}{c}\text { Std. } \\
\text { Dev. }\end{array}$ & $\begin{array}{c}\text { RII } \\
\text { (\%) }\end{array}$ & $\begin{array}{c}\text { T } \\
\text { Value }\end{array}$ & $\begin{array}{c}\text { P Value } \\
\text { Sig. }\end{array}$ & Rank \\
\hline A1 & $\begin{array}{c}\text { Labour } \\
\text { productivity }\end{array}$ & 3.71 & 0.78 & 74.29 & 8.08 & $0.000^{*}$ & 2 \\
\hline A2 & Project schedule & 3.42 & 0.94 & 68.31 & 3.89 & $0.000^{*}$ & 4 \\
\hline $\mathbf{A 3}$ & Quality & 3.91 & 0.88 & 78.18 & 9.10 & $0.000^{*}$ & 1 \\
\hline $\mathbf{A 4}$ & $\begin{array}{c}\text { Cost of } \\
\text { construction }\end{array}$ & 3.40 & 0.95 & 68.05 & 3.72 & $0.000^{*}$ & 5 \\
\hline A5 & $\begin{array}{c}\text { Client } \\
\text { satisfaction }\end{array}$ & 3.62 & 0.99 & 72.47 & 5.54 & $0.000^{*}$ & 3 \\
\hline \multicolumn{2}{|c|}{ All the items } & 3.61 & 0.62 & 72.26 & 8.64 & $0.000^{*}$ & \\
\hline
\end{tabular}

As categorised in Table 4, five items of the project parameter were affected by inadequate $H \& S$ interventions on project parameters (i.e., labour productivity, project schedule, quality, cost of construction, and, finally, client satisfaction). The results showed that quality was ranked in the first position, with an average weight of $78.18 \%$. Thus, the respondents agreed that inadequate $H \& S$ interventions significantly affect the quality of projects. Quality was the determinant that is most affected by $H \& S$ standards because compliance with the H\&S criteria ensures their capacity to execute the project with high quality. This criterion was considered critical class and was highly affected by H\&S standards. Furthermore, the results were in line with the findings [12] that the quality parameter was rated second in the five criteria. In the study [13], this criterion was ranked fourth in the seven criteria.

Furthermore, the results showed that labour productivity was ranked on the second position, with an average weight of $74.29 \%$. Thus, the respondents agreed that inadequate H\&S interventions have a high impact on labour productivity because providing a healthy and safe work environment for workers reduces the likelihood of injuries or diseases, thereby reducing the absence of workers and significantly increasing their motivation to perform their work out of a sense of interest. This criterion was considered critical class and was highly affected by health and safety standards. Additionally, the results were in line with the findings [12] that state that out of the seven parameters, labour productivity was ranked first with a percentage of $83.3 \%$.

The cost of construction received an average weight of $68.05 \%$ and the fifth rank. Several studies have referred to both the direct and indirect cost of construction affected by the degree of OHS commitment. This criterion was ranked last. However, this ranking does not mean that the criterion is unimportant; rather, it reflects the low level of awareness about the importance of OHS and its effect on the cost of construction. In another study [12], out of the seven criteria, this criterion was ranked second with a weight of $73.3 \%$.

\subsection{The Project Manager's Role in the Planning Phase}

This section contained 11 items, which were subjected to the views of respondents. The outcomes of the analysis are shown in Table $\mathbf{5}$. 
Table 5. The extent to which the project managers adhere to their roles in the planning phase.

\begin{tabular}{|c|c|c|c|c|c|c|c|}
\hline No. & Factors Related to the Planning Phase & Mean & Std. Dev. & RII (\%) & T Value & \begin{tabular}{c|c|} 
Value \\
Sig.
\end{tabular} & Rank \\
\hline $\begin{array}{ll}\mathrm{C} 1 \\
\end{array}$ & Setting H\&S objectives & 3.83 & 0.89 & 76.62 & 8.15 & $0.000^{*}$ & 3 \\
\hline $\mathrm{C} 2$ & Identifying specific safety issues from prior experience & 4.08 & 0.74 & 81.56 & 12.80 & $0.000 *$ & 1 \\
\hline $\mathrm{C} 3$ & Recognising the activities of the project within the OHS implications & 3.73 & 0.81 & 74.55 & 7.93 & $0.000 *$ & 4 \\
\hline $\mathrm{C} 4$ & $\begin{array}{l}\text { Preparing a checklist for classifying the hazards related to the construction activities } \\
\text { according to the hazard types }\end{array}$ & 3.66 & 0.80 & 73.25 & 7.22 & $0.000 *$ & 5 \\
\hline C5 & Consulting workers on $\mathrm{H} \& \mathrm{~S}$ issues & 3.43 & 0.97 & 68.57 & 3.90 & $0.000 *$ & 10 \\
\hline C6 & $\begin{array}{l}\text { Appointing a professional safety team and following the owner to follow up throughout the } \\
\text { project }\end{array}$ & 3.65 & 1.06 & 72.99 & 5.37 & $0.000 *$ & 6 \\
\hline C7 & Ensuring that the client allocates specific funds to promote project $\mathrm{H} \& \mathrm{~S}$ & 3.60 & 1.09 & 71.95 & 4.80 & $0.000 *$ & 7 \\
\hline C8 & Selecting a professional consultant to make a safe design & 3.45 & 1.15 & 69.09 & 3.46 & $0.001 *$ & 9 \\
\hline C9 & Providing adequate time and resources for all the stages of the project & 3.97 & 0.74 & 79.48 & 11.50 & $0.000 *$ & 2 \\
\hline $\mathrm{C} 10$ & Arranging for free health and safety training for the client staff & 3.40 & 1.19 & 68.05 & 2.96 & $0.004 *$ & 11 \\
\hline C11 & Defining ways to promote and consolidate OHS in the tender stage & 3.51 & 1.06 & 70.13 & 4.20 & $0.000 *$ & 8 \\
\hline & All the items & \begin{tabular}{|l|}
3.66 \\
\end{tabular} & 0.71 & 73.29 & 8.26 & 0.000* & - \\
\hline
\end{tabular}

The results illustrated that the total average of all the items in the third field (i.e., the role and responsibilities of the project manager in the planning phase) was 3.66, with the T-test value 8.26 and the $P$-value 0.000 , which is less than 0.05 . This indicates that the sample participants believed that the project manager adheres to his role and responsibility of promoting OHS at the planning phase to a great extent, meaning that the results were confident. As shown in Table 5, the average SD was 0.71 , which indicates that the results pertaining to the respondents were consistent and not spread out over a wider range of values. This means that results were confident.

The findings indicated that identifying specific safety issues from prior experience with mean index 4.08 and proportional weigh 81.56 was ranked the first in this field. It is clear from the results that project managers showed interest and benefit because of their experience in the previous projects in identifying $\mathrm{H} \& \mathrm{~S}$ issues in order to avoid any errors they experienced in the previous projects.

This was followed closely by the field of adequate resources and resources for all the phases, with an average of 3.97 and relative weight of $79.48 \%$. This finding indicates that project managers are interested in providing adequate resources and time to complete the project. This component is important in achieving safety by giving each task enough time to be accomplished in order to avoid accidents during the course of the work. This result was supported by the findings [34] as it was clear that one of the main causes of the incidents was insufficient resources and time to complete the projects.

The consulting workers on health and safety issues, with a mean index of 3.43 and proportional weight of $68.57 \%$, ranked $10^{\text {th }}$ from the $11^{\text {th }}$, meaning that the owners' representative did not pay much attention to consulting workers on H\&S-related issues, which is consistent with the findings of another study [29], which concluded that workers were not participating in the meetings related to the H\&S-related issues and accident investigation.

The arrangement for free H\&S training for the client staff, with a mean index of 3.40 and proportional weight of $68.05 \%$, was ranked the last. The reason for this may be the lack of awareness among owners' representatives regarding the importance of H\&S and its impact on the success of construc-tion projects.

\subsection{The Extent to which Project Managers Adhere to their Roles in the Designing Phase}

This section contained 13 items. These items were subjected to the views of the respondents. The outcomes of the analysis are shown in Table 6. The results illustrate that the total average for all the items in the third field of the extent to which the project managers adhere to the roles and responsibilities in the designing phase was 3.64 , with the T-test value 8.51 and the $P$-value equal 0.000 , which was less than 0.05 . This indicates that the sample participants believed that the project managers adhere to their role and responsibilities of promoting OHS at the designing phase to a great extent, suggesting that the results are confident. As Table $\mathbf{6}$ shows, the average SD was 0.66 , which indicates that the results pertaining to the respondents are consistent and not spread out over a wider range of values. This means that results are confident.

Table 6. The extent to which the project managers adhere to their roles in the designing phase.

\begin{tabular}{|c|c|c|c|c|c|c|c|}
\hline No. & Factors Related to the Designing Phase & Mean & Std. Dev. & RII (\%) & T Value & $\begin{array}{c}P \text { Value } \\
\text { Sig. }\end{array}$ & Rank \\
\hline D1 & Changing designers' mindsets towards safety & 3.68 & 1.01 & 73.51 & 5.89 & $0.000^{*}$ & 7 \\
\hline D2 & Ensuring that the designers have mentioned H\&S in the specific mission statement & 3.64 & 1.04 & 72.73 & 5.38 & $0.000 *$ & 8 \\
\hline D3 & Incorporating safety constructability principles into the design & 3.46 & 1.12 & 69.20 & 3.67 & $0.000^{*}$ & 13 \\
\hline
\end{tabular}


(Table 6) contd....

\begin{tabular}{|c|c|c|c|c|c|c|c|}
\hline No. & Factors Related to the Designing Phase & Mean & Std. Dev. & RII (\%) & T Value & $\begin{array}{c}P \text { Value } \\
\text { Sig. }\end{array}$ & Rank \\
\hline D4 & Ensuring that H\&S hazards are identified in the construction drawings & 3.60 & 0.98 & 71.95 & 5.37 & $0.000 *$ & 9 \\
\hline D5 & Ensuring that the process of identifying risks in the construction drawings are detailed & 3.47 & 1.12 & 69.35 & 3.67 & $0.000 *$ & 12 \\
\hline D6 & Ensure that hazardous material is taken into consideration when specifying materials & 3.69 & 0.88 & 73.77 & 6.88 & $0.000 *$ & 6 \\
\hline D7 & Providing a motivational force to promote safe design principles & 3.49 & 1.01 & 69.87 & 4.30 & $0.000^{*}$ & 11 \\
\hline D8 & $\begin{array}{l}\text { Ensuring that reasonable guidance is developed when new structures or new materials are } \\
\text { espoused in the project }\end{array}$ & 3.73 & 0.92 & 74.81 & 7.03 & $0.000 *$ & 3 \\
\hline D9 & $\begin{array}{l}\text { Planning works at the design phase through a time schedule by citing the duration of } \\
\text { processes and dividing it into steps and process priorities. }\end{array}$ & 3.94 & 0.69 & 78.70 & 11.81 & $0.000 *$ & 1 \\
\hline D10 & Seeking alternative design solutions to reduce health and safety risks wherever possible & 3.69 & 0.71 & 73.77 & 8.48 & $0.000^{*}$ & 5 \\
\hline D11 & Entering any design changes that affect $H \& S$ in the risk register & 3.74 & 0.78 & 74.81 & 8.28 & $0.000^{*}$ & 2 \\
\hline D12 & $\begin{array}{l}\text { Seeking approval and accreditation from the local regulatory bodies concerned with OHS } \\
\text { in the construction industry of the proposed design and implementation mechanisms }\end{array}$ & 3.71 & 1.00 & 74.29 & 6.28 & $0.000 *$ & 4 \\
\hline D13 & $\begin{array}{l}\text { Including the design for the period of implementation, operation, and maintenance of the } \\
\text { project, including the OHS standards for each stage }\end{array}$ & 3.52 & 0.88 & 70.39 & 5.16 & $0.000 *$ & 10 \\
\hline \multicolumn{2}{|r|}{ All the items } & 3.64 & 0.66 & 72.87 & 8.51 & $0.000 *$ & - \\
\hline
\end{tabular}

The findings indicated that the task of planning works at the design phase through a time schedule by citing the duration of processes and dividing into steps and process priorities (D9), with a mean index of 3.94 and proportional weight of .70\%, was ranked the first. This was due to the interest of the owners' representatives (i.e., the project managers) in good planning during the design phase by adhering to a timetable that shows the duration of each process and setting priorities so that the design period is given sufficient time to avoid any problems or accidents that may occur during the implementation phase. This result supports the findings of a study [49] as it is clear that the main mission of the safety and coordination plan is to prevent accidents through the plan works at the design phase.

The results also revealed that the task of entering any design changes that affect $H \& S$ in the risk register (D11), with a mean index of 3.74 and proportional weight of $74.81 \%$, was ranked in the second position in this field. The results confirmed that most of the owners' representatives were concerned with the process of recording any changes in the design that may adversely affect H\&S. This is a good indication of the commitment of the owners' representatives in the Gaza Strip towards the H\&S of the workers during the preconstruction phase.

Although a study [38] considered that $36 \%$ of the respondents indicated that constructability reviews were important while considering construction workers' safety during the design process, another study [30] showed that constructability reviews were the most common tool or process associated with adequate OHS during pre-construction phase. The result of this study showed that the item of item of incorporating safety constructability principles in the design, with a mean index of 3.46 and proportional weight of $69.20 \%$, was ranked the last due to the owners' representatives lack of knowledge about the principle of safety constructability.

\subsection{The Extent to which the Project Managers Adhere their Roles in the Tendering Phase}

This section contained 19 items. These items were subjected to the views of respondents. The outcomes of the analysis are shown in Table 7. The results illustrated that the total average of all the items in the third field of the extent to which the project managers adhere their roles in the tendering phase equalled to 3.61, with the T-test value 6.60 and the $P$ value 0.000 , which is less than 0.05 . This means that sample participants believed that the project manager adhered to their role and responsibility of promoting OHS at the tendering phase to a great extent, indicating that the results are confident. As shown in Table 7, the average SD was 0.81 , which indicates that the results pertaining to the respondents are consistent and not spread out over a wider range of values. This means that the results are confident.

Table 7. The extent to which the project managers adhere their roles in the tendering phase.

\begin{tabular}{|c|c|c|c|c|c|c|c|}
\hline No. & Factors Related to the Tendering Phase & Mean & $\begin{array}{l}\text { Std. } \\
\text { Dev. }\end{array}$ & RII (\%) & T Value & \begin{tabular}{|c|}
$P$ Value \\
Sig.
\end{tabular} & Rank \\
\hline E1 & $\begin{array}{l}\text { Ensuring that OHS is a portion of the main objectives of the project as it must be mentioned } \\
\text { in the subject matter of the tender }\end{array}$ & 3.78 & 0.97 & 75.58 & 7.06 & $0.000 *$ & 5 \\
\hline E2 & $\begin{array}{l}\text { Understanding the local market in order to evaluate the capability of consultants and } \\
\text { contractors to meet the required standards }\end{array}$ & 3.56 & 0.91 & 71.17 & 5.38 & $0.000 *$ & 10 \\
\hline E3 & $\begin{array}{l}\text { Ensuring that the technique used is sufficient for finding a firm that is financially stable, } \\
\text { with a good reputation, and well aware of the safety measures }\end{array}$ & 3.88 & 1.03 & 77.66 & 7.56 & $0.000 *$ & 3 \\
\hline E4 & $\begin{array}{c}\text { Reviewing the } \mathrm{CV} \text { of the main safety personnel provided by the contractor when assessing } \\
\text { them }\end{array}$ & 3.51 & 1.07 & 70.13 & 4.15 & $0.000 *$ & 12 \\
\hline E5 & $\begin{array}{c}\text { Reviewing the record on the OHS issues of the contractor such as fines, compliance with } \\
\text { reporting regulations, and accident frequency rate }\end{array}$ & 3.48 & 1.12 & 69.61 & 3.77 & $0.000 *$ & 13 \\
\hline
\end{tabular}


(Table 7) contd....

\begin{tabular}{|c|c|c|c|c|c|c|c|}
\hline No. & Factors Related to the Tendering Phase & Mean & $\begin{array}{l}\text { Std. } \\
\text { Dev. }\end{array}$ & RII (\%) & T Value & \begin{tabular}{|c|}
$P$ Value \\
Sig.
\end{tabular} & Rank \\
\hline E6 & Selecting subcontractors who have a good reputation and good record in OHS & 3.44 & 1.02 & 68.83 & 3.80 & $0.000 *$ & 15 \\
\hline E7 & Ensuring that the contractors put adequate provision for the H\&S costs in their proposals & 3.44 & 1.22 & 68.83 & 3.18 & $0.002 *$ & 16 \\
\hline E8 & $\begin{array}{l}\text { Requiring contractors firm to submit a master plan for OHS as a requirement to awarding } \\
\text { the tender }\end{array}$ & 3.75 & 1.03 & 75.06 & 6.43 & $0.000 *$ & 6 \\
\hline E9 & Requiring an emergency plan to be included in the contractor's safety programme & 3.62 & 1.09 & 72.47 & 5.03 & $0.000 *$ & 7 \\
\hline E10 & $\begin{array}{c}\text { Promoting awareness of occupational safety by attaching the Occupational Safety Law of } \\
\text { the Ministry of Labour within the tender documents }\end{array}$ & 3.58 & 1.07 & 71.69 & 4.80 & $0.000 *$ & 9 \\
\hline E11 & $\begin{array}{l}\text { Involving a clause in the contract documents that clarifies the lack of commitment to the } \\
\text { H\&S requirement is a cause for termination of the contract }\end{array}$ & 3.61 & 1.24 & 72.21 & 4.33 & $0.000 *$ & 8 \\
\hline E12 & $\begin{array}{l}\text { Detailing the items that include H\&S-related matters, which must be given the same weight } \\
\text { as other items. }\end{array}$ & 3.45 & 1.16 & 69.09 & 3.43 & $0.001 *$ & 14 \\
\hline E13 & Addressing H\&S matters during contract negotiation & 3.35 & 1.26 & 67.01 & 2.43 & $0.017 *$ & 17 \\
\hline E14 & $\begin{array}{l}\text { Considering the contractor who has responded well to the clause on H\&S matters during the } \\
\text { awarding process }\end{array}$ & 3.34 & 1.27 & 66.75 & 2.33 & $0.023 *$ & 18 \\
\hline E15 & $\begin{array}{l}\text { Ensuring that the contractor is committed to providing a permanent representative for health } \\
\text { and safety in the project }\end{array}$ & 3.31 & 1.30 & 66.23 & 2.10 & $0.039 *$ & 19 \\
\hline E16 & $\begin{array}{l}\text { Ensuring that the contractor complies with safety inspection procedures routinely in order to } \\
\text { minimise unexpected risks. }\end{array}$ & 3.52 & 1.19 & 70.39 & 3.84 & $0.000 *$ & 11 \\
\hline E17 & Ensuring that the contractor offers basic welfare facilities such as toilets and drinking water & 3.83 & 0.94 & 76.62 & 7.78 & $0.000^{*}$ & 4 \\
\hline E18 & $\begin{array}{l}\text { Ensuring that personal protective equiproject managerent (PPE) is provided to all the } \\
\text { workers for free }\end{array}$ & 3.99 & 0.73 & 79.74 & 11.79 & $0.000 *$ & 2 \\
\hline E19 & $\begin{array}{l}\text { Ensuring that first aid and emergency medical treatment are provided on-site in the case of } \\
\text { accidents }\end{array}$ & 4.06 & 0.82 & 81.30 & 11.44 & $0.000 *$ & 1 \\
\hline \multicolumn{2}{|r|}{ All the items } & 3.61 & 0.81 & 72.20 & 6.60 & $0.000 *$ & - \\
\hline
\end{tabular}

The findings indicated that the item of ensuring that first aid and emergency medical treatment are provided on site in the case of accidents (E19), with a mean index of 4.06 and proportional weight of $81.30 \%$, has the highest rank in this field. This is because the culture of the owner's representatives concerning OHS is largely confined to providing first aid and emergency medical treatment in the event of an accident. This finding matches with that of the study [50], which confirms the need to meet the owner's requirements related to OHS. These requirements include medical examinations, first aid, and emergency facilities.

The results also revealed that the item of ensuring that Personal Protective Equiproject managerent (PPE) is provided to all the workers for free (E18), with a mean index of 3.99 and proportional weight of $79.74 \%$, was ranked in the second position in this field. This is due to the same reasons stated in the previous paragraph. Moreover, this finding also supports a study [51], which indicates the importance of meeting the owners' requirements concerning OHS to reduce disputes and misunderstanding in the construction phase. One of these requirements is a provision for personnel protective equiproject managerent.

Considering the contractor who has responded well to the clause on H\&S matters during the awarding process (E14), with a mean index of 3.34 and proportional weight of $66.75 \%$, was ranked $18^{\text {th }}$ out of 19 in this field. This is because awarding projects in the Gaza Strip depends mostly on the lowest prices. This finding matches with a study [31], which concludes that there are five criteria to select the contractor and conduct the evaluation. The last rank was given to $\mathrm{H} \& \mathrm{~S}$.

Ensuring the contractor is committed to providing a permanent representative for $\mathrm{H} \& \mathrm{~S}$ in the project (E15), with a mean index of 3.31 and proportional weight of $66.23 \%$, was ranked in the last position in this field due to the lack of safety culture of the owners' representatives and their belief that appointing a dedicated safety team in the site would be an additional cost to the project. This finding was in contrast with a study [29], which concludes that the presence of H\&S representatives on site is an important part of the success of the project and is ranked third out of the 20 because their presence encourages all the participants to commit to H\&S-related issues.

\section{CONCLUSIONS AND RECOMMENDATIONS}

\section{General Conclusions}

- This study confirmed that inadequate H\&S intervention has a significant impact on project parameters, especially the quality of the project and labour productivity.

- Project managers in the Gaza Strip have awareness regarding their responsibilities concerning OHS practices and clauses in the construction projects during the pre-construction phase, and especially during the planning stage. However; certain responsibilities have their shortcomings, as mentioned before.

- This study confirmed that the project managers adhere to their role in dealing with the H\&S-related issues in the pre-construction phase, and any H\&Srelated problems occurring during the implementation phase shall also be the responsibility of the owner's representative and not the sole responsibility of the contractor. However, the negligence of the contractor in complying with the owner's instructions always 
makes the contractor liable.

- The tendering stage is one of the most important phases, in which the owner can modify and correct the defects that may take place in the previous two stages (i.e., planning and tendering) to promote certain concepts through the requirements that are included in the tender documents, in which the contractor is asked to carry in their consideration during the pricing process.

\section{RECOMMENDATIONS}

- Safety and health should be an important parameter by all the participants in construction projects on a level equal to the traditional project parameters, namely, cost, quality time, and client satisfaction.

- The lawmakers and governmental entities need to offer more motivation to comply with $H \& S$ terms in order to help contractors improve the H\&S performance of the projects and, consequently, improve construction workers' performance.

- According to design-related aspects, project managers should refer to H\&S more frequently in details, finishes, and different characteristics of mate-rials.

- Owner representatives should integrate design and construction process, recognise client requirements, ensure the designs are finalised before starting the construction process, pre-qualify contractors on $\mathrm{H} \& \mathrm{~S}$, which include the financial budget for H\&S in the contract documentation, and stop using competitive tendering.

- Owing to carelessness in H\&S recording, the occupational safety grade of each project should be reviewed as well as evaluated. Moreover, a special report should be publicised, which is one of the most important criteria for selecting the contractor.

- The criteria of classification of consultancy offices should be reconsidered to bring a safety engineer within the companies' permanent staff.

\section{CONSENT FOR PUBLICATION}

Not applicable.

\section{FUNDING}

None.

\section{AVAILABILITY OF DATA AND MATERIALS}

Not applicable.

\section{CONFLICT OF INTEREST}

The authors declare no conflict of interest, financial or otherwise

\section{ACKNOWLEDGEMENTS}

Declared none.

\section{REFERENCES}

[1] Y. Le, M. Shan, A.P. Chan, and Y. Hu, "Overview of corruption research in construction", ASCE. J. Construct. Engin. Management, vol. 30 , no. 4,2014

[http://dx.doi.org/10.1061/(ASCE)ME.1943-5479.0000300]

[2] R.K. Ghaben, and A.A. Jaaron, "Identifying and assessing innovation factors in construction projects in Palestine: An empirical study", Int. J. Project Organ. Manage., vol. 9, no. 4, pp. 350-370, 2017.

[http://dx.doi.org/10.1504/IJPOM.2017.088250]

[3] H. Zahoor, A.P. Chan, R. Masood, R.M. Choudhry, A.A. Javed, and W.P. Utama, "Occupational safety and health performance in the Pakistani construction industry: Stakeholders' perspective", Int. J. Construct. Management, vol. 16, no. 3, pp. 209-219, 2016. [http://dx.doi.org/10.1080/15623599.2015.1138027]

[4] A.S. Suleiman, "The realization of Palestinian construction project managers on the importance of project management training programs", Int. J. Adv. Acade. Rese., (Engineering)., vol. 2, no. 1, pp. $1-12,2016$.

[5] S. Laryea, and S. Mensah, "Health and safety on construction sites in Ghana", The Construction, Building and Real Estate Research Conference of the Royal Institution of Chartered Surveyors, Dauphine Université, Paris, 2010.

[6] E. Jazayeri, and G. Dadi, "Construction safety management systems and methods of safety performance measurement: A review", J. Safety. Engineering., vol. 6, no. 2, pp. 15-28, 2017.

[7] M.T. Newaz, P.R. Davis, and M. Jefferies, "Developing a safety climate factor model in construction research and practice", Eng. Construct. Architect. Manag., vol. 25, no. 6, pp. 738-757, 2018. [http://dx.doi.org/10.1108/ECAM-02-2017-0038]

[8] M. Saïdani, A. Shibani, and M. Alhajeri, "Health and safety influence on the construction project performance in United Arab Emirates (UAE)", Prime. J., vol. 3, no. 2, pp. 442-452, 2013.

[9] M. Afzini, and B. Neyestani, "Occupational health and safety in construction", Ph.D. thesis, De La Salle University, Manila, Metro Manila, Philippines, 2017.

[10] N. Chileshe, and E. Dzisi, "Benefits and barriers of construction health and safety management (HSM)", J. Engin. Design. Technol., vol. 10, no. 2, pp. 276-298, 2012

[http://dx.doi.org/10.1108/17260531211241220]

[11] L.A. AbuHamra, and A.A. Enshassi, "Strategies for safety and productivity improvement", J. Engin. Res. Technol., vol. 2, no. 1, pp. 65-74, 2015.

[12] W.Y. Ayessaki, and J. Smallwood, "Influencing workers' performance through health and safety interventions", Procedia Eng., vol. 182, pp. 42-49, 2016.

[http://dx.doi.org/10.1016/j.proeng.2017.03.111]

[13] J. Smallwood, and D. Venter, "The influence of project managers on construction health and safety in South Africa", Aus. J. Construct. Economic. Building, vol. 2, no. 1, pp. 57-69, 2012 [http://dx.doi.org/10.5130/AJCEB.v2i1.2887]

[14] C. Deacon, and J. Smallwood, "The effect of the integration of design, procurement and construction relative to health and safety", $\mathrm{PhD}$. Thesis., International Seeds Conference, Leeds Beckett University, Leeds, United Kingdom, 2016.

[15] S. Laryea, R. Leiringer, and W. Hughes, "Proceedings of the West Africa built environment research. Ghana", In: West Africa Built Environment Research, Accra: Ghana, 2010.

[16] M. Frijah, The role of owner in fostering construction safety during the pre-construction phase in Gaza Strip., South Central Library: Gaza, 2017.

[17] A. Enshassi, S. Mohamed, and S. Abushaban, "Factors affecting the performance of construction projects in the Gaza strip", J. Civ. Eng. Manag., vol. 15, no. 3, pp. 269-280, 2009.

[http://dx.doi.org/10.3846/1392-3730.2009.15.269-280]

[18] A. Enshassi, S. Mohamed, Z. Abu Mustafa, and P.E. Mayer, "Factors affecting labour productivity in building projects in the Gaza strip", $J$ Civ. Eng. Manag., vol. 13, no. 4, pp. 245-254, 2010. [http://dx.doi.org/10.3846/13923730.2007.9636444]

[19] J. Smallwood, and T.C. Haupt, "The need for construction health and safety (H\&S) and the construction regulations: Engineers' perceptions", J. South African, vol. 47, no. 2, pp. 2-8, 2005.

[20] V. Okorie, "Behaviour-based health and safety management in construction: a leadership-focused approach", In: CIB W099 International Health and Safety, Belfast, 2014.

[21] B. Endroyo, A. Suraji, and M.S. Besari, "Model of the maturity of preconstruction safety planning", Procedia Eng., vol. 171, pp. 413-418, 2016.

[http://dx.doi.org/10.1016/j.proeng.2017.01.351]

[22] A. Heravi, V. Coffey, and B. Trigunarsyah, "Evaluating the level of 
stakeholder involvement during the project planning processes of building projects", Int. J. Proj. Manag., vol. 33, no. 5, pp. 1-47, 2015. [http://dx.doi.org/10.1016/j.ijproman.2014.12.007]

[23] N.M. Saifullah, and F. Ismail, "Integration of occupational safety and health during preconstruction stage in malaysia", Procedia Soc. Behav. Sci., vol. 35, pp. 603-610, 2012

[http://dx.doi.org/10.1016/j.sbspro.2012.02.127]

[24] A.E-S. Mohamed, "The implementation of building information modeling (bim) towards sustainable construction industry in Egypt", M.Sc. Thesis, Graduate School of Education, The American University in Cairo, Cairo, Egypt, 2018.

[25] H. Lingard, P. Pirzadeh, R. Wakefield, and B.M. Kleiner, "Exploring the link between early constructor involvement in project decision making and the efficacy of health and safety risk control", Construct. Manag. Econ., vol. 32, no. 9, pp. 1-20, 2014 [http://dx.doi.org/10.1080/01446193.2014.911931]

[26] P.A. Manu, D. Proverbs, N. Ankrah, and S. Suresh, "The health and safety impact of construction project features", Eng. Construct. Architect. Manag., vol. 21, no. 1, pp. 65-93, 2014. [http://dx.doi.org/10.1108/ECAM-07-2012-0070]

[27] J.A. Gambatese, M. Behm, and S. Rajendran, "Design's role in construction accident causality and prevention: Perspectives from an expert panel", Saf. Sci., vol. 46, pp. 675-691, 2008. [http://dx.doi.org/10.1016/j.ssci.2007.06.010]

[28] E. Koehn, and N.K. Datta, "Quality, environmental, and health and safety management systems for construction engineering", J. Constr. Eng. Manage., vol. 129, no. 5, 2003. [http://dx.doi.org/10.1061/(ASCE)0733-9364(2003)129:5(562)]

[29] E.M. Mwanaumo, "An integrated approach to multi-stakeholder interventions in construction health and safety", D.Phil. Thesis., University of Johannesburg, South Africa, 2013.

[30] B. Vermeulen, "The role of a design engineer in safety of building projects", MEng Thesis, Stellenbosch University, Stellenbosch, South Africa, 2014.

[31] E.A. Ghaith, "The impact of lowest bidding bid awarding system on construction project quality in Gaza Strip", MEng Thesis, The Islamic University of Gaza, Gaza, Palestin, 2018.

[32] A. Oke, C. Aigbavboa, and M. Seemola, "Importance of safety guidelines on South African construction sites", International Conference on Applied Human Factors and Ergonomics, 2018pp. 153-160

[http://dx.doi.org/10.1007/978-3-319-60525-8_16]

[33] I. Musonda, and J.H. Pretorius, "Effectiveness of economic incentives on clients' participation in health and safety programmes", J. South African Institut. Civil Engineering, vol. 57, no. 2, pp. 2-7, 2015. [http://dx.doi.org/10.17159/2309-8775/2015/V57N2A1]

[34] P. Hughes, and E. Ferrett, Introduction to health and safety in construction., NEBOSH, 2011.

[35] P. Pirzadeh, H. Lingard, T.H. Mills, and B.M. Kleiner, "Proactive evaluation of occupational health and safety performance in construction projects using the hierarchy of controls concept", Proceedings of CIB W099 International Health and Safety Conference: Benefitting Workers and Society through Inherently Safe(r) Construction (CIB W099), 2015 Belfast, Northern Ireland, 2015

[36] L. Zhang, H. Chen, H. Li, X. Wu, and M.J. Skibniewski, "Perceiving interactions and dynamics of safety leadership in construction projects", Saf. Sci., vol. 106, pp. 66-78, 2018. [http://dx.doi.org/10.1016/j.ssci.2018.03.007]

[37] I. Cameron, and B. Hare, "Planning tools for integrating health and safety in construction", Construct. Manage. Economics, pp. 899-909, 2008.

[38] T.M. Tool, D.A. Abowitz, and J.A. Gambatese, Owners' role in facilitating designing for construction safety., The Center for Construction Research and Training, 2012.

[39] A. Enshassi, M.A. Faisal, and B.A. Tayeh, "Subcontractor prequalification practices in Palestine", Int. J. Construct. Management, vol. 10, pp. 45-75, 2010.

[http://dx.doi.org/10.1080/15623599.2010.10773154]

[40] A. Enshassi, M.A. Faisal, and B.A. Tayeh, "Relationship between general contractors and subcontractors in the palestinian construction industry", Int. J. Proj. Plann. Finance, vol. 2, pp. 41-65, 2011.

[41] A. Enshassi, F. Arain, and B.A. Tayeh, "Major causes of problems between contractors and subcontractors in the Gaza Strip", J. Financ. Manage. Property. Construction, vol. 17, no. 1, pp. 92-112, 2012. [http://dx.doi.org/10.1108/13664381211211064]

[42] K. El-Hallaq, and B.A. Tayeh, "Strategic planning in construction companies in Gaza Strip", J. Engineer. Res. Technology, vol. 2, no. 2, pp. 167-174, 2015.

[43] B.A. Tayeh, K. Al-Hallaq, and F.A. Sabha, "Effects of faulty design phase on school buildings maintenance in Gaza Strip", Am. J. Civil. Engineer. Architect., vol. 4, no. 6, pp. 199-210, 2016

[44] B.A. Tayeh, K. Al-Hallaq, M.O. Yusuf, and F.A. Sabha, "Effects of construction phase errors on maintenance of school buildings in Gaza Strip", Int. J. Manage. Inform. Technol. Engineering, IJMITE., vol. 5, no. 01, pp. 21-34, 2017.

[45] B.A. Tayeh, K. Al-Hallaq, A.H. Al Faqawi, W.S. Alaloul, and S.Y. Kim, "Success factors and barriers of last planner system implementation in the Gaza Strip construction industry", Open Constr. Build. Technol. J., vol. 12, no. 1, pp. 389-403, 2018. [http://dx.doi.org/10.2174/1874836801812010389]

[46] B.A. Tayeh, K. Al-Hallaq, W.S. Alaloul, and A.R. Kuhail, "Factors affecting the success of construction projects in Gaza Strip", Open Civ. Eng. J., vol. 12, pp. 301-315, 2018.

[http://dx.doi.org/10.2174/1874149501812010301]

[47] O.A. Tayeh, K. El-Hallaq, and B.A. Tayeh, "The organizational culture of Gaza Strip construction companies", Int. J. Engineer. Manage. Res., vol. 8, no. 01, pp. 40-64, 2018.

[48] O.A. Tayeh, K. El-Hallaq, and B.A. Tayeh, "Importance of organizational culture for Gaza Strip construction companies", Int. J. Engineer. Manage. Res., vol. 8, no. 1, pp. 35-39, 2018.

[49] A. Gottfried, G. Giuda, V. Villa, and P. Piantanida, "The evolution of legislation on health and safety on construction site in Italy", Research, Development and Practice in Structural Engineering and Construction, 2012 ASEA-SEC-1, Perth, November 28-December 2, 2012.

[http://dx.doi.org/10.3850/978-981-08-7920-4_CS-3-0146]

[50] J. Wells, Promoting construction health and safety through procurement: A briefing note for developing countries., Institute of Civil Engineers ICE, 2015

[51] K. Mahfuth, A. Loulizi, B.A. Tayeh, and K. Al-Hallaq, "Unacceptable forms of work for safety in the construction sector- Palestinian National Authority", Int. J. Engineer. Technol., vol. 9, no. 13, pp. 328-341, 2018.

\section{C) 2020 Tayeh et al.}

This is an open access article distributed under the terms of the Creative Commons Attribution 4.0 International Public License (CC-BY 4.0), a copy of which is available at: https://creativecommons.org/licenses/by/4.0/legalcode. This license permits unrestricted use, distribution, and reproduction in any medium, provided the original author and source are credited. 